Jurnal MAKSIPRENEUR, Vol. VI, No. 1, Desember 2016, hal. 24 - 36

\title{
FAKTOR - FAKTOR PENENTU KEBERHASILAN USAHA KECIL DAN MENENGAH (UKM) DI KOTA YOGYAKARTA
}

Eny Sulistyowati (sulis1165@gmail.com)

Fakultas Ekonomi Universitas Proklamasi 45

Nining Sofiati Lestari (niningsofiatilestari@gmail.com)

Fakultas Ilmu Sosial dan Ilmu Politik Universitas Proklamasi 45

\begin{abstract}
This research was conducted with the aim to explain the influence of the characteristics of the owner/manager of the business strategy, describes the influence of business strategy on business performance, explaining the influence of the characteristics of the owner / manager of the business performance. Variables used in this research is variable owner / manager, business strategy (independent variable) and variable performance or Small Bussinis Performance (dependent variable). The results obtained show that a direct influence on the performance characteristics of the manager of small and medium businesses in the city of Yogyakarta strong with R2 values of 0.224 , or $22.4 \%$, the effect of business strategies on business performance of small and medium businesses in urban areas with $R 2$ values of 0,049 or 4.9\%. Meanwhile, indirectly influence the characteristics of managers' business performance through business strategy in the city of Yogyakarta only has value R2 value of 0.080 or $8.0 \%$.
\end{abstract}

Keywords : small and medium enterprises, character owner/manager, strategic planning, performance

\section{PENDAHULUAN}

Sebuah kondisi nyata yang tidak dapat dipungkiri lagi bahwa UKM (Usaha Kecil Menengah) adalah sektor ekonomi nasional yang paling strategis dan menyangkut hajat hidup orang banyak, sehingga menjadi tulang punggung perekonomian nasional. Data jumlah UMKM di propinsi DIY selalu mengalami peningkatan dari 149.320 unit pada tahun 2007 menjadi 204.979 unit pada tahun 2013 (Data Dinas Perindustrian, Perdagangan, Koperasi dan UKM DIY). Peningkatan UMKM di Daerah Istimewa Yogyakarta ini salah satunya disebabkan karena semakin meningkatnya lulusan sarjana, tidak diimbangi dengan ketersediaan lapangan pekerjaan yang memadai. Sektor UMKM bisa menjadi solusi untuk mengurangi tingkat pengangguran tenaga kerja khususnya di wilayah Daerah Istimewa Yogyakarta. Usaha kecil dan menengah bisa menjadi solusi karena modal yang dibutuhkan relatif kecil dengan mayoritas pasar adalah pasar lokal. Selain itu juga diimbangi dengan pola konsumsi masyarakat yang cenderung meningkat sehingga mendukung tingginya tingkat permintaan.

Mengingat peran strategis UKM di Indonesia, maka sangat disayangkan jika sektor ini tidak diberdayakan secara optimal oleh pemerintah. Pemberdayaan sebenarnya dapat dilakukan diantaranya dengan mengidentifikasi masalah yang ada di sektor UMKM. Salah satu upaya yang sudah dilakukan pemerintah melalui Kementerian Koperasi dan UMKM 
adalah mencanangkan pertumbuhan 6 juta unit usaha baru di Indonesia selama periode tahun 2005 - 2009. Sekitar 5,3 juta unit usaha baru diprediksikan akan tumbuh secara alami pada sektor-sektor ekonomi yang telah ada, sedang 700.000 unit usaha baru perlu diarahkan pada sektor-sektor usaha yang berbasis pengetahuan dan teknologi serta sektor yang mampu meningkatkan produktivitas dan daya saing perekonomian nasional (Lestari, 2007).

Pertumbuhan usaha kecil merupakan masalah yang kompleks dan multidimensi dalam lingkup dan karakter. Hal ini mencakup konvergensi dari ambisi pemilik-manajer, dan kompetensi, faktor-faktor internal organisasi, sumberdaya spesifik dan infrastruktur, hubungan ekternal dan konfigurasi jaringan (Shaw and Conway, 2000).

Faktor yang mempengaruhi keberhasilan small business/usaha kecil penting untuk diketahui karena masih rendahnya tingkat keberhasilan small business/ usaha kecil. Kirby (2003) menyatakan bahwa usaha kecil menengah memiliki beberapa masalah dalam pertumbuhannya. Masalah tersebut disebabkan kurangnya nilai-nilai entrepreneur, pembiayaan, dan pasar. Faktor-faktor eksternal lainnya seperti lingkungan maroeconomic, kebijakan dan peraturan pemerintah, dan ketersediaan prasarana fisik juga mempengaruhi pertumbuhan. Oleh karena itu penelitian ini dilakukan dengan judul: FAKTOR - FAKTOR PENENTU KEBERHASILAN USAHA KECIL DAN MENENGAH (UKM) DI KOTA YOGYAKARTA

Berdasarkan latar belakang di atas maka yang menjadi permasalahan dalam penelitian ini adalah : Apakah karakteristik owner/manager berpengaruh terhadap strategis bisnis?, Apakah strategi bisnis berpengaruh terhadap kinerja bisnis?, Apakah karakteristik owner/manager berpengaruh terhadap kinerja bisnis?

Menurut Sugiyono (2002) variabel adalah suatu faktor atau sifat atau nilai dari orang, obyek atau kegiatan yang mempunyai variasi yang ditetapkan oleh peneliti untuk dipelajari dan ditarik kesimpulan. Berdasarkan pengertian di atas, maka variabel yang digunakan dalam penelitian ini meliputi owner/manager, strategi bisnis (variabel independen) dan variabel kinerja atau Small Bussinis Performance (variabel dependen).

\section{Owner/manager characteristics}

Merupakan karakteristik individu yang dimiliki pemilik/pengusaha. Indikator pengukuran yang membedakan karakteristik pemilik/pengusaha meliputi: Menyukai Risiko, Inovasi, Kerja Keras Tanggung Jawab dan Percaya Diri, Pengalaman Usaha dan Optimis.

\section{Strategi bisnis}

Strategi bisnis merupakan kemampuan pemilik/pengusaha dalam menganalisis lingkungan eksternal dan internal perusahaan, perumusan strategi, pelaksanaan rencanarencana usaha untuk mencapai tujuan perusahaan, serta melakukan evaluasi untuk mendapatkan umpan balik dalam merumuskan strategi yang akan datang. Indikator-indikator yang digunakan adalah:a. Strategic planning, b. Financial strategy, c. Human resource strategy, $d$. Operations strategy.

\section{Small business performance}

Small business performance merupakan tingkat pencapaian atau prestasi usaha kecil yang dicapai dalam kurun waktu tertentu. Variabel kinerja dalam penelitian ini terdiri atas: Peningkatan penjualan, Peningkatan produktifitas dan Peningkatan keuntungan. 
Tujuan yang ingin dicapai dalam penelitian adalah:

a. menjelaskan pengaruh karakteristik owner/manager terhadap strategis bisnis,

b. menjelaskan pengaruh strategi bisnis terhadap kinerja bisnis,

c. menjelaskan pengaruh karakteristik owner/manager terhadap kinerja bisnis

Sedangkan manfaat hasil penelitian diharapkan dapat memberi kontribusi terhadap ilmu pengetahuan sebagai bahan kajian lebih lanjut dalam mengembangkan penelitian tentang faktor keberhasilan pelaku Usaha Kecil Mikro (UKM) dan pihak pemerintah daerah khususnya dinas terkait, sehingga bisa memberikan masukan untuk perbaikan dan upaya peningkatan kinerja Usaha Kecil Mikro (UKM) sehingga mampu meningkatkan taraf hidup masyarakat kota Yogyakarta.

\section{TINJAUAN PUSTAKA}

\subsection{Usaha Kecil Menengah (UKM)}

Naisbitt dalam bukunya Global Paradox meramalkan bahwa semakin besar dan terbuka ekonomi dunia, maka semakin banyak perusahaan kecil dan menengah akan mendominasi. Perusahaan kecil di masa datang akan memainkan peran utama dalam percaturan ekonomi dunia karena mereka memiliki efisiensi yang tinggi disertai dengan akses yang lebih luas untuk menjankau peluang ekonomi dunia. Menurut Naisbitt, kontribusi perusahaan besar di Amerika Serikat hanya 10\%, sisanya didominasi oleh perusahaan kecil dan menengah. Jumlah UKM di Amerika Serikat terus meningkat. Menurut data tahun 2008, ada 3.705.275 usaha yang memiliki pekerja 1 - 4 orang (industri rumahan), 1.060.250 perusahaan memiliki pekerja 5-9 orang (usaha kecil), 644.842 perusahaan mempekerjakan 10-19 pekerja (usaha menengah) dan 532.391 perusahaan memiliki karyawan 20-99 orang (www.census.gov/econ/smallbus.html).

Kecenderungan perubahan struktur ekonomi dunia dari konglomerasi menuju ekonomi kecil dan menengah juga dirasakan di Indonesia. Ketika perusahaan besar ambruk terhantam krisis, banyak perusahaan kecil dengan tingkat ketergantungan terhadap bank dan pasar saham yang relatif kecil tetap dapat bertahan. Kalau mau jujur, usaha kecil dan menengah yang telah menghambat kehancuran ekonomi Indonesia secara total. Kondisi seperti ini sebenarnya membuktikan bahwa ideologi dasar negara mengenai ekonomi kerakyatan sebenarnya sangat relevan dengan kondisi saat ini. Oleh karena itu perlu kembali ditingkatkan program-program peningkatan kinerja usaha kecil dan menengah.

Ada dua definisi usaha kecil yang dikenal di Indonesia. Pertama, definisi usaha kecil menurut Undang-Undang No. 20 tahun 2008 tentang Usaha Mikro, Kecil, dan Menengah adalah usaha ekonomi produktif yang berdiri sendiri, yang dilakukan oleh orang perorangan atau badan usaha yang bukan merupakan anak perusahaan atau bukan cabang perusahaan yang dimiliki, dikuasai, atau menjadi bagian baik langsung maupun tidak langsung dari usaha menengah atau usaha besar yang memenuhi kriteria Usaha Kecil sebagaimana dimaksud dalam Undang-Undang no 20 Tahun 2008. Kriteria tersebut antara lain memiliki kekayaan bersih lebih dari Rp. 50.000.000,00 (lima puluh juta rupiah) sampai dengan paling banyak Rp. 500.000.000,00 (lima ratus juta rupiah) tidak termasuk tanah dan bangunan tempat usaha atau memiliki hasil penjualan tahunan lebih dari Rp. 300.000.000,00 (tiga ratus juta rupiah) sampai dengan paling banyak Rp. 2.500.000.000,00 (dua milyar lima ratus juta rupiah). Kedua, menurut kategori Badan Pusat Statistik (BPS), usaha kecil identik dengan industri kecil dan industri rumah tangga. BPS mengklasifikasikan industri berdasarkan jumlah pekerjanya, yaitu: (1) industri rumah tangga dengan pekerja 1-4 orang; (2) industri kecil 
dengan pekerja 5-19 orang; (3) industri menengah dengan pekerja 20-99 orang; (4) industri besar dengan pekerja 100 orang atau lebih (BPS, 1999:250).

\subsection{Manajer}

Manajer adalah seseorang yang bekerja melalui orang lain dengan mengkoordinasikan kegiatan-kegiatan mereka guna mencapai sasaran organisasi. Pada organisasi berstruktur tradisional, manajer sering dikelompokkan menjadi manajer puncak, manajer tingkat menengah, dan manajer lini pertama (biasanya digambarkan dengan bentuk piramida, di mana jumlah karyawan lebih besar di bagian bawah daripada di puncak).

Robert L. Katz pada tahun 1970-an mengemukakan bahwa setiap manajer membutuhkan minimal tiga keterampilan dasar. Ketiga keterampilan tersebut adalah:

1) Keterampilan konseptual (conceptional skill)

Manajer tingkat atas (top manager) harus memiliki keterampilan untuk membuat konsep, ide, dan gagasan demi kemajuan organisasi. Gagasan atau ide serta konsep tersebut kemudian haruslah dijabarkan menjadi suatu rencana kegiatan untuk mewujudkan gagasan atau konsepnya itu. Proses penjabaran ide menjadi suatu rencana kerja yang kongkret itu biasanya disebut sebagai proses perencanaan atau planning. Oleh karena itu, keterampilan konsepsional juga meruipakan keterampilan untuk membuat rencana kerja.

2) Keterampilan berhubungan dengan orang lain (humanity skill)

Selain kemampuan konsepsional, manajer juga perlu dilengkapi dengan keterampilan berkomunikasi atau keterampilan berhubungan dengan orang lain, yang disebut juga keterampilan kemanusiaan. Komunikasi yang persuasif harus selalu diciptakan oleh manajer terhadap bawahan yang dipimpinnya. Dengan komunikasi yang persuasif, bersahabat, dan kebapakan akan membuat karyawan merasa dihargai dan kemudian mereka akan bersikap terbuka kepada atasan.

3) Keterampilan teknis (technical skill)

Keterampilan ini pada umumnya merupakan bekal bagi manajer pada tingkat yang lebih rendah. Keterampilan teknis ini merupakan kemampuan untuk menjalankan suatu pekerjaan tertentu, misalnya menggunakan program komputer, memperbaiki mesin, membuat kursi, akuntansi dan lain-lain. Merupakan kemampuan untuk mendefinisikan masalah dan menentukan cara terbaik dalam memecahkannya. Kemampuan membuat keputusan adalah yang paling utama bagi seorang manajer, terutama bagi kelompok manajer atas (top manager). Griffin mengajukan tiga langkah dalam pembuatan keputusan. Pertama, seorang manajer harus mendefinisikan masalah dan mencari berbagai alternatif yang dapat diambil untuk menyelesaikannya. Kedua, manajer harus mengevaluasi setiap alternatif yang ada dan memilih sebuah alternatif yang dianggap paling baik. Dan terakhir, manajer harus mengimplementasikan alternatif yang telah ia pilih serta mengawasi dan mengevaluasinya agar tetap berada di jalur yang benar. (Ref :Wikipidea,organisasi.org,ronnysiagian.wordpress.com\& komfemeureudu.blogspot.co

m)

\subsection{Strategi Bisnis}

Literatur manajemen stratejik memberikan pandangan pada peranan penting strategi bisnis pada keseluruhan perusahaan skala besar dan kecil. Perusahaan menggunakan strategi bisnis untuk memberikan acuan bagi langkah fundamental yang mereka rencanakan untuk di jalankan sesuai dengan tujuan mereka. Hal ini mengindikasikan bahwa organisasi dapat memiliki strategi tunggal atau berbagai strategi, dan bahwa strategi tersebut sepertinya ada 
pada tiga level: strategi level korporat; strategi level bisnis; dan strategi level fungsional. Meskipun literatur memberikan saran bahwa strategi dikembangkan pada tiga tingkatan berbeda, studi teoritik dan empirik hubungan antara strategi dan kinerja organisasi memiliki pandangan utama pada strategi bisnis. Penelitian empirik sebelumnya pada hubungan strategi /kinerja memiliki fokus pada perusahaan besar. Studi ini menyediakan bukti yang kuat yang menyarankan bahwa strategi bisnis terkait dengan kinerja perusahaan besar. Meskipun sebagian besar studi empirik berpusat pada perusahaan besar, sebagian kecil penelitian mengindikasikan bahwa strategi bisnis dapat juga mempengaruhi perusahaan yang lebih kecil. Porter (1980) mencatatkan bahwa perusahaan dapat meraih keunggulan kompetitif melalui value yang dihasilkan bagi customer. Porter memberikan kesimpulan bahwa strategi bisnis yang berbasis pada aktivitas tersebut dikenal sebagai strategi generik. Untuk berkinerja di atas rata-rata, sebuah perusahaan harus ada selangkah di depan kompetitor dan meningkatkan pangsa pasarnya (Porter 1991). Pangsa pasar ditingkatkan dengan menarik konsumen baru dan mempertahankan konsumen yang ada. Keunggulan dan cakupan dari produk yang ditawarkan oleh perusahaan juga akan menentukan kemampuannya untuk menarik konsumen baru. Aktivitas yang berkaitan dengan peningkatan pangsa pasar termasuk : peningkatan produk yang ada untuk memenuhi permintaan konsumen yang berubah ubah; Pengembangan produk produk baru; dan penekanan kualitas produk (Zeithaml dan Fry 1984; Robinson dan Pearce 1988).

Kinerja dari sebuah usaha ditentukan oleh strategi bisnis yang diterapkannya (Pearce dan Robinson, 1985; Olson \& Bokor, 1995). Sebuah strategi bisnis adalah sebuah rencana tindakan keseluruhan (Plan of actions) yang menentukan posisi kompetitif dari sebuah perusahaan (Mintzeberg \& Quinn, 1991). Strategi bisnis diterapkan melalui strategi fungsional utama dari pemasaran, keuangan, manajemen dan sumber daya manusia, produksi, serta penelitian dan pengembangan. Kemudian, masing-masing strategi fungsional ini tersusun atas beberapa aktivitas. Maka aktivitas bertindak sebagai petunjuk untuk realisasi strategi bisnis keseluruhan (Nath \& Sudharson, 1994).

\subsection{Small business performance / Kinerja}

Kinerja adalah merujuk pada tingkat pencapaian atau prestasi perusahaan dalam periode waktu tertentu. Kinerja (performance) perusahaan dapat dilihat dari tingkat penjualan, tingkat keuntungan, tingkat pengembalian modal, tingkat turn over dan pangsa pasar yang diraih (Jauch andG lueck, 1998).

Laitinen (2002) menunjukkan bahwa kinerja dapat didefinisikan sebagai kemampuan suatu obyek sehingga menghasilkan hasil dalam dimensi yang ditentukan secara a priori, dalam kaitannya dengan target. Ia juga menunjukkan bahwa sistem terorganisir dengan baik pengukuran kinerja mungkin merupakan mekanisme yang paling kuat dari manajemen untuk meningkatkan probabilitas implementasi strategi yang berhasil. Indikator kinerja yang paling sering digunakan adalah omset penjualan (O'Regan et al, 2004) menggunakan kinerja keuangan dengan menggunakan laba kotor per karyawan sebagai pengukuran kinerja.

Meskipun beberapa studi menemukan perusahaan berbeda di dalam negara yang berbeda memberikan pandangan pada tujuan yang berbeda. (Nash, 1993) menyatakan bahwa profitabilitas adalah indikator terbaik untuk mengidentifikasi ketika organisasi menjalankan hal yang benar dan profitabilitas dapat digunakan sebagai pengukuran primer dari keberhasilan perusahaan. Lebih jauh lagi, (Doyle, 1994) menunjukkan bahwa profitabilitas adalah pengukuran paling umum pada kinerja di perusahaan barat. Profit margin, return, on assets, retun on equity, return on sales dipertimbangkan menjadi pengukuran umum dalam profitabilitas finansial. Abu Kassim et al (1989) menemukan bahwa sales, sales growth, net 
profit dan gross profit merupakan pengukuran finansial yang dijalankan oleh perusahaan manufakturing di malaysia. Untuk berkinerja di atas rata-rata sebuah perusahaan harus ada selangkah di depan competitor dan meningkatkan pangsa pasarnya (Porter, 1991). Kinerja dari sebuah usaha ditentukan oleh strategi bisnis yang diterapkannya (Pearce \& Robinson, 1985; Olson \& Bokor, 1995).

Terkait dengan pengertian kinerja, terdapat beberapa pendapat dari para tokoh, diantaranya Mulyadi (2007: 337) yang menyatakan bahwa: "kinerja adalah keberhasilan personel, tim, atau unit organisasi dalam mewujudkan sasaran strategik yang telah ditetapkan sebelumnya dengan perilaku yang diharapkan”. Pendapat yang lain mengenai definisi kinerja juga diungkapkan oleh Indra Bastian (2006: 274) yang menyatakan bahwa: Kinerja adalah gambaran pencapaian pelaksanaan suatu kegiatan/program/kebijaksanaan dalam mewujudkan sasaran, tujuan, misi, dan visi organisasi. Secara umum, kinerja merupakan prestasi yang dicapai oleh organisasi dalam periode tertentu.

Berdasarkan pembahasan tinjauan pustaka di atas dalam penelitian ini digunakan Kerangka Penelitian sbb:

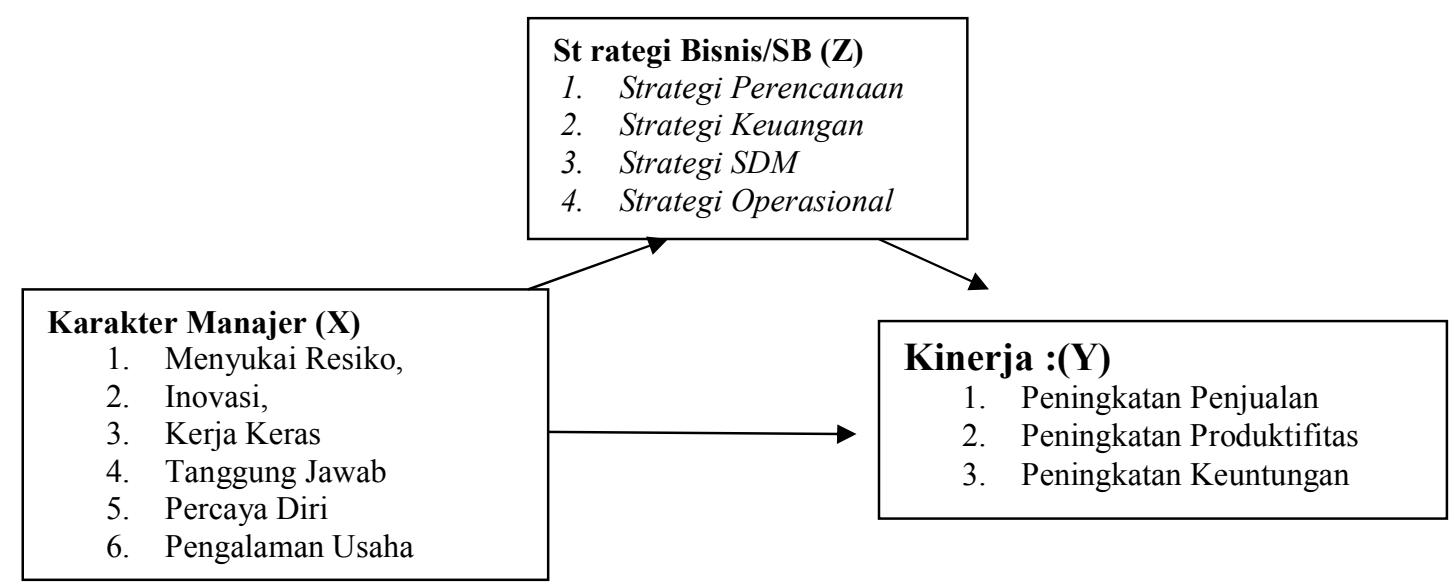

Sumber : Diolah dari berbagai literatur

Berdasarkan kerangka pemikiran di atas, maka dapat diajukan hipotesis penelitian sebagai berikut:

H1. Owner/manajer characteristics berpengaruh positif terhadap strategi bisnis

H2. Strategi bisnis berpengaruh positif terhadap kinerja

H3. Owner/manajer characteristics berpengaruh positif terhadap kinerja

\section{METODE PENELITIAN}

\subsection{Populasi}

Populasi dalam penelitian ini adalah seluruh entrepreneur yang sekaligus pemilik dan manajer usaha skala kecil dan menengah yang ada di wilayah Kecamatan Danurejan, Kecamatan Kota Gede, Kecamatan Umbulharjo, Kecamatan Gedong Tengen dan Kecamatan Ngampilan Kota Yogyakarta yang sudah menjalankan usahanya minimal 2 tahun. Untuk mempermudah pembatasan sampel digunakan metode pengambilan sampel dengan metode purposive sampling dengan kriteria: lokasi usaha berada di wilayah Kecamatan Danurejan, Kecamatan Kota Gede, Kecamatan Umbulharjo, Kecamatan Gedong Tengen dan Kecamatan 
Ngampilan Yogyakarta, usahanya telah berjalan minimal 2 tahun. Berdasarkan kriteria tersebut maka sampel yang akan digunakan dalam penelitian ini sebanyak 50 usaha kecil.

\subsection{Teknik Pengumpulan Data}

Pengumpulan data dilakukan menggunakan kuesioner, yang berupa daftar pertanyaan yang disusun dengan Skala Likert lima poin, skor 5 untuk menunjukkan kesetujuan dan skor 1 menunjukkan ketidaksetujuan terhadap pernyataan yang diajukan. Untuk menyebarkan kuesioner kepada responden peneliti berkoordinasi dan berkomunikasi dengan Dinas Perindustrian Perdagangan Koperasi dan Pertanian Kota Yogyakarta. Kuesioner tersebut kemudian minta diisikan oleh pelaku usaha kecil di wialayah penelitian yang menjadi sampel.

Kuesioner ini diperoleh dari instrumen yang digunakan oleh Parasuraman dkk (dalam Kotler, 1997; 23) yang disebut SERVQUAL. Instrumen variabel-variabel yang terdapat dalam kuesioner yang meliputi variabel karakteristik manajer, strategi bisnis dan kinerja.

\subsection{Metode Analisis Data}

1) Pengujian Validitas dan Reliabilitas

Sebelum instrumen penelitian ini disebarkan kepada responden, maka perlu diuji validitasnya terlebih dahulu. Hal ini dilakukan untuk mengetahui ketepatan dan kecermatan suatu alat ukur dalam melaksanakan fungsi ukurnya. Analisa ini dilakukan dengan mengidentifikasi apakah indikator-indikator yang digunakan dapat mengkonfirmasi sebuah konstruk Rule of thumb yang digunakan dalam penelitian ini adalah factor loading harus lebih atau sama dengan 0,40 (Hair et al, 1998). Dalam menilai reliabilitas data, digunakan nilai Cronbach's Alpha yang bertujuan untuk mengetahui kekonsistenan suatu alat ukur dalam mengukur. Dalam penelitian ini akan digunakan analisis koefisien minimal 0,60. Hal ini masih dikarenakan menurut Hair et al. (2006) nilai ini masih dapat diterima.

\section{2) Analisis Statistik}

Pengujian persyaratan analisa data yang digunakan yaitu uji normalitas, uji heteroskedasitas dan uji multikolinieritas.

a. Uji Normalitas

Uji normalitas bertujuan untuk menguji apakah dalam model regresi, variabel terikat dan variabel bebas keduanya mempunyai distribusi normal atau tidak. Untuk menguji apakah distribusi data normal atau tidak dapat dilakukan beberapa cara adalah analisis grafik. Indikasi metode analisis grafik pada uji normalitas adalah melihat normal probability plot yang membandingkan distribusi kumulatif dari data sesungguhnya dengan distribusi kumulatif dari distribusi normal. Jika distribusi data adalah normal, maka garis yang menggambarkan data sesungguhnya akan mengikuti garis diagonalnya.

\section{b. Uji Heteroskedastisitas}

Heteroskedastisitas menyatakan bahwa varian bersyarat variabel $\mathrm{Y}$ meningkat bersama dengan meningkatnya variabel $X$, hingga menunjukkan penyebaran yang tak sama atau varian linier klasik adalah bahwa gangguan $V_{i}$ yang muncul dalam fungsi regresi populasi adalah homokedastisitas yaitu semua gangguan tadi mempunyai varian yang sama. Salah satu cara untuk mendeteksi masalah heteroskedaktisitas dengan dengan melihat pola yang jelas penyebaran data pada scatter plot Jika ada pola yang jelas, serta titik-titik menyebar di atas dan di bawah angka 0 pada sumbu Y, maka tidak terjadi heteroskedastisitas. 
c. Uji Multikolinieritas

Uji ini bertujuan untuk menguji apakah model regresi ditemukan adanya korelasi antar variabel bebas (independen). Model regresi yang baik seharusnya tidak terjadi korelasi di antara variabel independen. Jika variabel independen saling berkorelasi, maka variabelvariabel ini tidak ortogonal (Ghozali 2007:91). Untuk mendeteksi adanya multikolinearitas, dapat dilihat dari Value Inflation Factor (VIF). Apabila nilai VIF $>10$, terjadi multikolinieritas. Sebaliknya, jika VIF $<10$, tidak terjadi multikolinearitas.

d. Analisis Path (Jalur)

Kuncoro dan Ridwan (2007: 1-2). Model path analysis digunakan untuk menganalisis pola hubungan antar variabel dengan tujuan untuk mengetahui pengaruh langsung maupun tidak langsung seperangkat variabel bebas (eksogen) terhadap variabel terikat (endogen). (Kuncoro dan Ridwan. 2007: 2).

Langkah-langkah menguji path analysis sebagai berikut:

1. Merumuskan hipotesis dan persamaan struktural

$\mathbf{Y}=\rho_{\mathrm{yx} 1} \mathrm{X}_{1}+\rho_{\mathrm{yx} 2} \mathrm{X}_{2}+\rho_{\mathrm{y}} \varepsilon_{1}$

2. Menghitung koefisien jalur yang didasarkan pada koefisien regresi

Hipotesis: naik turunnya variabel endogen $(\mathrm{Y})$ dipengaruhi secara signifikan oleh variabel eksogen $\left(\mathrm{X}_{1}\right.$ dan $\left.\mathrm{X}_{2}\right)$.

Menghitung koefisien regresi untuk strukur yang telah dirumuskan.

Persamaan regresi ganda: $\mathrm{Y}=\mathrm{a}+\mathrm{b} 1 \mathrm{x} 1+\mathrm{b} 1 \times 2+\varepsilon 1$

Kaidah pengujian signifikan secara manual: menggunakan tabel $\mathrm{F}$

$$
F=\frac{(\mathrm{n}-\mathrm{k}-1) \mathrm{R}^{2} y x \mathrm{k}}{K\left(1-R^{2} y x \mathrm{k}\right)}
$$

Jika $F_{\text {hitung }} \geq \mathrm{F}_{\text {tabel, }}$, maka tolak Ho artinya signifikan dan $\mathrm{F}_{\text {hitung }}<\mathrm{F}_{\text {tabel, }}$ terima Ho artinya tidak signifikan. Taraf signifikan yang digunakan $<(\alpha)$ yaitu 0.05 .

3. Menghitung koefisien jalur secara individu

Hipotesis penelitian yang akan diuji dirumuskan menjadi hipotesis statistik berikut:

Ha: $\rho Y X 1>0$ dan jika Ho: $\rho Y X 1=0$

Secara individual uji statistik yang digunakan adalah uji $t$ yang dihitung dengan rumus (Kusnendi, 2005: 12)

$$
t_{\mathrm{k}}=\frac{\rho_{\mathrm{k}}}{\mathrm{se}_{\mathrm{p}^{\mathrm{k}}}} ;(\mathrm{dk}=\mathrm{n}-\mathrm{k}-1)
$$

- Jika nilai probabilitas 0.05 lebih kecil atau sama dengan nilai probabilitas Sig atau $(0.05 \leq \mathrm{Sig})$, maka Ho diterima dan Ha ditolak, artinya tidak signifikan.

- Jika nilai probabilitas 0.05 lebih besar atau sama dengan nilai probabilitas Sig atau $(0.05 \geq$ Sig)

e. Uji Hipotesis

Analisis regresi pada dasarnya adalah studi mengenai ketergantungan variabel dependen dengan satu atau lebih variabel independen. dengan tujuan untuk mengestimasi dan atau memprediksi rata-rata populasi atau nilai rata-rata variabel dependen berdasarkan nilai variabel yang diketahui (Gujarati, 2003 dalam Ghozali. 2007).

Menurut Ghozali (2007) ketepatan fungsi regresi sampel dalam menaksir nilai aktual dapat diukur dari Goodness of fit-nya. Secara statistik, setidaknya ini dapat diukur dari nilai koefisien determinasi dan nilai statistik F. Perhitungan statistik disebut signifikan secara statistik apabila nilai uji statistiknya berada dalam daerah kritis (daerah dimana $\mathrm{H}_{0}$ ditolak). 
Uji $\mathrm{F}$ dapat juga dilakukan dengan melihat nilai signifikansi $\mathrm{F}$ pada output hasil regresi menggunakan SPSS 21.0 dengan significance level $0.05(\alpha=5 \%)$. Jika nilai signifikansi lebih besar dari $\alpha$ maka hipotesis ditolak, yang berarti model regresi tidak fit. Jika nilai signifikan lebih kecil dari $\alpha$ maka hipotesis diterima, yang berarti bahwa model regresi fit.

\section{f. Koefisien Determinasi}

Koefisien determinasi $\left(\mathrm{R}^{2}\right)$ pada intinya mengukur seberapa jauh kemampuan model dalam menerangkan variasi variabel dependen. Nilai koefisien determinasi adalah antara nol dan satu. Nilai $\mathrm{R}^{2}$ yang kecil berarti kemampuan variabel variabel independen dalam menjelaskan variasi variabel dependen amat terbatas. Nilai yang mendekati satu berarti variabel-variabel independen memberikan hampir semua informasi yang dibutuhkan untuk memprediksi variasi variabel dependen.

\section{HASIL PENELITIAN DAN PEMBAHASAN}

Hasil analisis data yang didasarkan 50 buah kuesioner yang semuanya kembali dan bisa diolah datanya seperti sebagai berikut:

1. Semua responden sudah berstatus menikah atau berkeluarga. Jumlah responden dengan jenis kelamin wanita sebanyak 30 orang atau $60 \%$. Usia responden didominasi responden dengan usia $51-60$ tahun sebanyak 23 orang atau $46 \%$. Usia $<30$ tahun sebanyak 2 orang atau 4\%, usia 30 - 40 tahun sebanyak 6 orang atau 12\%, usia $41-$ 50 tahun sebanyak 11 orang atau $22 \%$, dan usia $>60$ tahun sebanyak 8 orang atau 16\%. Sementara Pendidikan responden didominasi responden dengan pendidikan D3 sebanyak 23 orang atau $46 \%$. Pendidikan SMA sebanyak 17 orang atau 34\%, pendidikan S1 sebanyak 8 orang atau 16\% dan pendidikan S2 sebanyak 2 orang atau $4 \%$.

2. Jenis usaha yang dilakukan oleh responden adalah 14 orang atau $28 \%$ usaha di bidang kuliner, sebanyak 13 orang atau $26 \%$ usaha di bidang jasa dan sisanya 23 orang atau $46 \%$ berusaha lain diluar usaha kuliner dan jasa. 46 orang atau 92\% responden yang telah menjalankan usaha lebih dari 2 tahun

3. Berdasarkan Uji Validitas dan Uji Reliabilitas Dari 12 item pertanyaan variabel karakteristik manajer yang diajukan pada responden penelitian menunjukkan semua $\mathrm{r}_{\text {sig }}$ di atas ketentuan nilai $r_{x y}(0.40)$. Hal ini dapat dikatakan bahwa item pertanyaan yang diajukan untuk variabel karakteristik manajer adalah valid.

Dari 8 item pertanyaan variabel strategi bisnis yang diajukan pada responden penelitian menunjukkan semua $r_{\text {sig }}$ di atas ketentuan nilai $r_{x y}(0.40)$. Hal ini dapat dikatakan bahwa item pertanyaan yang diajukan untuk variabel strategi bisnis adalah valid.

Dari 6 item pertanyaan variabel kinerja yang diajukan pada responden penelitian menunjukkan semua $r_{\text {sig }}$ di atas ketentuan nilai $r_{x y}(0.40)$. Dengan demikian, pada penelitian nantinya item pertanyaan nomor 8 tidak digunakan. Dengan hasil uji validitas ini dapat dikatakan bahwa item pertanyaan yang diajukan untuk variabel kinerja adalah valid.

Dari ketiga variabel penelitian menunjukkan hasil uji reliabilitas dengan nilai Cronbach Alpha $>0.6$. dengan demikian variabel yang digunakan dalam penelitian dapat dikatakan reliable.

4. Berdasarkan uji model rehresi; Hasil uji normalitas yang menunjukkan sebaran data di sekeliling garis lurus tersebut (tidak terpencar jauh dari garis lurus yang berarti model regresi linier dalam penelitian ini yaitu variabel terikat variabel bebas dan variabel 
moderasi ketiganya mempunyai distribusi normal sehingga dapat dikatakan bahwa persyaratan normalitas bisa dipenuhi.

Semua variabel dalam instrumen penelitian menunjukkan nilai VIF kurang dari 10. Dengan demikian dapat dikatakan bahwa variabel yang digunakan dalam penelitian ini terbebas dari gejala multikolinieritas.

Tidak ada pola yang jelas serta titik-titik menyebar maka tidak terjadi heteroskedastisitas. Sehingga dapat dikatakan bahwa dalam penelitian ini model regresi yang digunakan tidak terjadi ketidaksamaan varian dari residual dalam suatu pengamatan ke pengamatan yang lain.

5. Analisis Jalur (Path Analysis)

Menguraikan signifikansi tiap-tiap jalur dalam model dengan menggunakan analisis jalur. Masing-masing jalur yang diuji mewakili hipotesis yang ada di dalam penelitian ini. Adapun hasil olah data dapat dilihat sebagai berikut:

a. Pengujian Hipotesis Pertama

H0: Owner/manajer characteristics tidak berpengaruh positif terhadap strategi bisnis Ha: Owner/manajer characteristics berpengaruh positif terhadap strategi bisnis

Dari hasil perhitungan analisis jalur menggunakan program SPSS Versi 21.0 pada tingkat kepercayaan 5\% diperoleh koefisien jalur (beta) sebesar 0,283 dengan nilai $p$-value sebesar 0,000 . Oleh karena $p$-value $<$ a atau $0,000<0,050$ maka pernyataan H0 ditolak. Dengan kata lain, karakteristik manajer (KM) berpengaruh positif terhadap strategi bisnis (SB).

b. Pengujian Hipotesis Kedua

H0: Strategi bisnis tidak berpengaruh positif terhadap kinerja.

Ha: Strategi bisnis berpengaruh positif terhadap kinerja.

Dari hasil perhitungan analisis jalur menggunakan program SPSS Versi 21.0 pada tingkat kepercayaan 5\% diperoleh koefisien jalur (beta) sebesar 0,221 dengan nilai $p$-value sebesar 0,000. Oleh karena $p$-value $<$ a atau $0,000<0,050$ maka pernyataan H0 ditolak. Dengan kata lain, Strategi Bisnis(SB) berpengaruh positif terhadap Kinerja(K).

c. Pengujian Hipotesis Ketiga

$\mathrm{H} 0$ : Owner/manajer characteristics tidak berpengaruh positif terhadap kinerja

Ha: Owner/manajer characteristics berpengaruh positif terhadap kinerja

Dari hasil perhitungan analisis jalur menggunakan program SPSS Versi 21.0 pada tingkat kepercayaan 5\% diperoleh koefisien jalur (beta) sebesar 0,473 dengan nilai $p$-value sebesar 0,000 . Oleh karena $p$-value $<$ a atau $0,000<0,050$ maka pernyataan H0 ditolak. Dengan kata lain, karakteristik manajer(KM) berpengaruh positif terhadap kinerja(K).

d. Perhitungan Koefisien Jalur

Bagian ini menjelaskan tentang perhitungan pengaruh karakteritik manajer (KM) secara langsung maupun tidak langsung terhadap strategi bisnis (SB) melalui variabel intervening yaitu kinerja $(\mathrm{K})$. Sebelum menguji ada tidaknya pengaruh langsung maupun tidak langsung tersebut, masing-masing jalur terlebih dahulu diuji signifikansi tiap jalur. Apabila terdapat jalur yang tidak signifikan maka diberlakukan trimming theory yaitu dengan menghilangkan atau menghapus jalur yang tidak signifikan. Kemudian dari hasil struktur yang baru tersebut dihitung kembali masing-masing koefisien jalurnya (path coefficien). Berdasarkan hasil tersebut dapat diketahui besarnya pengaruh baik langsung, tidak langsung maupun 
pengaruh totalnya. Berikut ditampilkan model hipotesis beserta koefisien jalurnya pada Gambar 4.3.

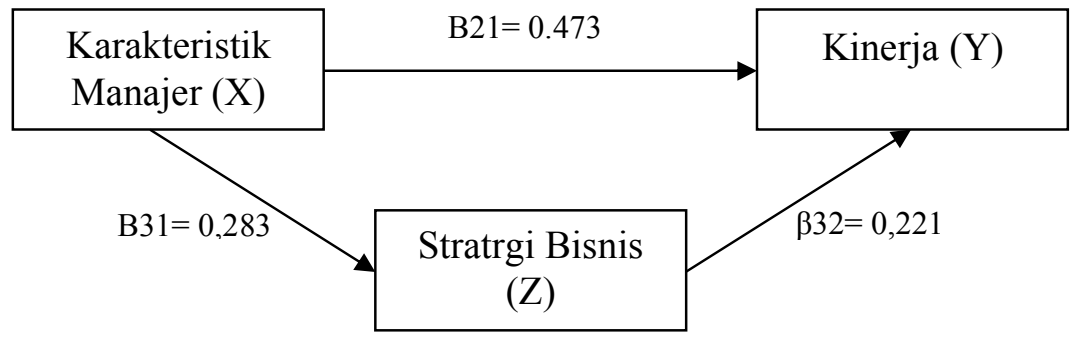

Sumber: data primer diolah 2016

\section{Gambar 4.3 Model Analisis Jalur}

Langkah berikutnya adalah menghitung pengaruh langsung dan tidak langsung karakteristik manajer sebagai variabel bebas terhadap kinerja sebagai variabel terikat melalui strategi bisnis sebagai variabel intervening serta menghitung residual variable $(\varepsilon)$ atau variabel sisa, yaitu variabel selain variabel $\mathrm{X}$ dan $\mathrm{Z}$ yang juga mempengaruhi $\mathrm{Y}$ tetapi tidak dimasukkan dalam penelitian.

a. Menghitung pengaruh $\mathrm{X}$ terhadap $\mathrm{Y}$ :

Pengaruh langsung:

$\mathrm{Y}=\beta_{31}=\beta_{2} \mathrm{X}+\mathrm{e}_{2}=(0,473)(0,473)=0,224$

Pengaruh tidak langsung:

$$
\begin{array}{ll}
\mathrm{Z} & =\beta_{21}=\beta_{1} \mathrm{X}+\mathrm{e}_{1} \\
\mathrm{Y} & =\beta_{32}=\beta_{3} \mathrm{Z}+\mathrm{e}_{2}
\end{array}
$$

atau

$Y=\beta_{21} \times \beta_{32}=\beta_{2} X+\beta_{3} Z+e_{2}=(0,283)(0,221)=0,063$

Pengaruh total $=$ pengaruh langsung + pengaruh tidak langsung

$$
=0,224+0,063=0,287 \text { atau } 28,7 \%
$$

b. Menghitung pengaruh $\mathrm{Z}$ terhadap $\mathrm{Y}$

Pengaruh langsung

$\mathrm{Y}=\beta_{3} \mathrm{Z}+\mathrm{e}_{2}=(0,221)(0,221)=0,049$

Pengaruh tidak langsung $=$ Tidak ada

Pengaruh total $=$ pengaruh langsung $=0,049$ atau $4,9 \%$

c. Analisis perbandingan antara:

$\mathrm{Y}=\beta_{31}=\beta_{2} \mathrm{X}+\mathrm{e}_{2}-=0,287$ dengan

$\mathrm{Y}=\beta_{21} \times \beta_{32}=\beta_{2} \mathrm{X} \times \beta_{3} Z+\mathrm{e}_{2}=0,049$

Berdasarkan hasil perhitungan koefisien jalur, tampak bahwa total efek dari karakteristik manajer terhadap strategi bisnis adalah 28,7\%, dengan perincian efek langsungnya sebesar $22,4 \%$ sedangkan efek tidak langsungnya sebesar $6,3 \%$. Variabel intervening, yaitu strategi bisnis juga dinyatakan memiliki pengaruh walaupun hanya berupa pengaruh langsung terhadap kinerja yaitu sebesar $4,9 \%$ yang juga merupakan pengaruh total dari variabel strategi bisnis terhadap variabel kinerja.

Hasil tersebut menyatakan bahwa pengaruh terbesar baik secara langsung maupun tidak langsung adalah dari variabel karakteristik manajer. Pengaruh langsung 
karakteristik manajer lebih besar daripada pengaruh tidak langsungnya, hal ini berarti bahwa jalur yang paling kuat adalah jalur antara karakteristik manajer terhadap kinerja tanpa melalui variabel strategi bisnis.

Berdasarkan uji olah data yang dilakukan diketahui bahwa bilai signifikansi $\mathrm{F}$ sebesar $0.000(<\alpha)$. Degan demikian dapat dikatakan bahwa model regresi yang digunakan dalam penelitian ini telah fit.

6. Pembahasan Pengaruh Karakteristik Manajer Terhadap Kinerja

Dalam pengujian hipotesis menggunakan analisis jalur, data menunjukkan bukti bahwa karakteristik manajer dapat mempengaruhi kinerja UKM di kota Yogyakarta. Hal ini disebabkan karena karakteristik manajer akan (menyukai resiko, inovatif, kerja keras, tanggung jawab, optimis dan berpengalaman) akan memberikan kesempatan untuk memperoleh hasil yang baik atau dengan kata lain memiliki kinerja usaha yang baik.

Pengaruh langsung yang ditimbulkan oleh karakteristik manajer terhadap kinerja berdasarkan nilai koefisien determinasi parsial $\left(\mathrm{R}^{2}\right)$ adalah sebesar $22,4 \%$. Dilihat dari besarnya, artinya sumbangan kualitas karakteristik manajer terhadap kinerja adalah sebesar $22,40 \%$.

7. Pembahasan Pengaruh Karakteristik manajer Terhadap Strategi Bisnis Hipotesis yang diajukan untuk karakteristik manajer terhadap strategi bisnis terbukti signifikan. Keadaan tersebut terjadi karena manajer atau pemilik usaha yang memiliki sikap senang terhadap resiko akan cenderung bekerja keras agar bisa mengalahkan atau meminimalkan resiko bisnis yang akan terjadi. Demikian juga seorang manajer yang inovatif, berpengalaman dan optimis akan mendorong semangat usaha yang tinggi sehingga akan bisa merumuskan strategi bisnis yang dianggap tepat.

8. Pembahasan Pengaruh Strategi Bisnis Terhadap Kinerja

Berdasarkan pengujian menggunakan analisis jalur tampak bahwa strategi bisnis berpengaruh nyata dan positif terhadap kinerja. Berdasarkan nilai koefisien determinasi parsial $\left(\mathrm{R}^{2}\right)$ sebesar 4,9\% strategi bisnis memberikan sumbangan kepada kinerja yaitu sebesar 4,9\%. Dari hasil tersebut dapat disimpulkan bahwa strategi bisnis berpengaruh pada kinerja meskipun kecil pengaruhnya.

9. Pembahasan Perbandingan Pengaruh Langsung dan Tidak Langsung Antara Karakteristik Manajer Terhadap Kinerja

Berdasarkan hasil perhitungan analisis jalur maka tampak bahwa pengaruh langsung karakteristik manajer terhadap kinerja adalah sebesar 22,4\%, sedangkan pengaruh tidak langsungnya sebesar $6,3 \%$. Jadi, pengaruh totalnya sebesar $28,7 \%$. Dari data di atas tampak bahwa pengaruh langsung lebih besar daripada pengaruh tidak langsung. Pengaruh langsung yang lebih besar kemungkinan disebabkan kinerja dari pelaku usaha lebih dipengaruhi oleh karakteristik manajer atau pemiliknya. Sehingga dapat disimpulkan bahwa jalur yang paling kuat adalah X langsung ke $\mathrm{Y}$.

\section{KESIMPULAN \& SARAN}

1. Kesimpulan

Pengaruh secara langsung karakteristik manajer terhadap kinerja pelaku usaha kecil menengah di kota Yogyakarta kuat. Hal ini dibuktikan dengan nilai $\mathrm{R}^{2}$ sebesar 0,224 atau 22,4\%. Pengaruh strategi bisnis terhadap kinerja usaha pelaku bisnis kecil dan menengah di wilayah kota Yogyakarta kurang kuat. Hal ini dibuktikan dengan nilai $\mathrm{R}^{2}$ sebesar 0,049 atau 4,9\%. Sedangkan pengaruh secara tidak langsung karakteristik manajer terhadap kinerja usaha melalui strategi bisnis di wilayah kota Yogyakarta 
hanya memiliki nilai nilai $\mathrm{R}^{2}$ sebesar 0,080 atau $8,0 \%$. Hal ini mengandung arti bahwa strategi bisnis kurang kuat terhadap kinerja usaha dari pelaku usaha mikro di wilayah kota Yogyakarta.

2. Saran

Dalam usaha meningkatkan kinerja pelaku usaha di wilayah kota Yogyakarta maka para pelaku usaha perlu meningkatkan strategi bisnis yang bisa meningkatkan daya saing usahanya sehingga bisa merebut konsumen.

\section{DAFTAR PUSTAKA}

Kuncoro. Achmad Engkos dan Ridwan. 2007. Cara Menggunakan dan Memakai Analisis Jalur (Path Analysis). Bandung: Penerbit Alfabeta.

Lestari, Sri., 2007. Kajian Model Penumbuhan Unit Usaha Baru. Jurnal Usaha Mikro Kecil dan Menengah.

Littunen, Hannu, 2000, Entreprenuership and Characteristies of The Entreprenuership Personality: International Journal of Entreprenuerial ehaviour and Research, Vol. 6. No. 6, 2000, pp. 295-309.

Shaw, E., and S. Conway, 2000. "Networking and the Small Firm," in Enterprise and Small Business. Ed. S. Carter and D. Jones-Evans. Harlow, UK: Financial Times/Prentice Hall, 367-383.

Statistik Usaha Kecil dan Menengah Tahun 2008. Kementerian Negara Koperasi \& UKM bekerjasama dengan Badan Pusat Statistik.

Sugiyono. 2004. Metode Penelitian Bisnis. Bandung: Alfabeta.

Undang Undang Nomer 20 tahun 2008 tentang Usaha Mikro Kecil dan Menengah.

Wikipidea, organisasi.org, ronnysiagian.wordpress.com \& komfe-meureudu.blogspot.com O'Regan, Nicholas, Martin Sims and Abby Ghobadian, 2005, High Performance: Owenership and Decision Making in SME's, Management Decision, Vol 43 No. 3 p. 382.

.........(www.census.gov/econ/smallbus.html).

Zeithaml. C., P., and L.W. Fry (1984). “ Contextual and Strategic Differences AmongMature Business in Four Dynamic Performance Situations, ” Academy of Management Journal 27.p.841- 